\title{
Two Decades of Lexicographica Series Maior
}

\author{
Reinhard Hartmann, Exeter, United Kingdom (r.r.k.hartmann@ex.ac.uk)
}

No stagnation of lexicography is to be expected, but on the contrary further flourishing. Ladislav Zgusta (1991: 3165)

\begin{abstract}
This article is a personal account, from the point of view of one of its editors, of the publishing history of Lexicographica Series Maior.

Keywords: LEXICOGRAPHICA SERIES MAIOR, PUBLISHING HISTORY, METALEXICOGRAPHY, LEXICOGRAPHY

Opsomming: Twee dekades van Lexicographica Series Maior. Hierdie artikel is 'n persoonlike weergawe, uit die gesigspunt van een van sy redakteurs, van die publikasiegeskiedenis van Lexicographica Series Maior.
\end{abstract}

Sleutelwoorde: LEXICOGRAPHICA SERIES MAIOR, PUBLIKASIEGESKIEDENIS, METALEKSIKOGRAFIE, LEKSIKOGRAFIE

\section{The first volume(s)}

It was exactly 20 years ago, while I was editing the proceedings of the LEXeter ' 83 Conference for publication as Volume 1 in the Lexicographica Series Maior (Hartmann 1984), that I wondered what all this would lead to. At a preliminary meeting in Exeter (not the one that led to the creation of the three-volume encyclopedia of lexicography, Wörterbücher/Dictionaries/Dictionnaires, edited by Franz Josef Hausmann et al. 1989-91), two or three of the conference participants who later became editors decided that the time was ripe for an international book series specialising in lexicography, and the German publisher Niemeyer at the same time agreed to take this on, together with the associated periodical Lexicographica. International Annual for Lexicography. However, none of us could have foreseen then that by the end of 2003, the book series would have grown to 114 titles since 1984 and the journal to 19 yearly issues since 1985.

In 1988, when LexSM had produced more than 20 volumes (six on average for each of the first four years), I referred to it as a 'basic training library' on the grounds that it seemed to contain "all the major aspects in the theory and practice of dictionary making" (Hartmann 1988: 151). This characterisation is even 
more appropriate today, as the published volumes represent what I have called a "wide thematic orientation and coverage" (Hartmann 2000: 4) in terms of the whole range of current perspectives, from dictionary history and dictionary typology to dictionary criticism, and from dictionary use and dictionary structure to computational lexicography. This article ${ }^{1}$ asks whether the ambitious aims of spanning the whole spectrum of lexicography and contributing to its 'further flourishing' have been achieved.

\section{Plans and policies}

From the start, we have had an editorial team of seven 'leaders' in the field, currently consisting of Ladislav Zgusta (USA), Sture Allén (Sweden), Franz Josef Hausmann, Oskar Reichmann and Ulrich Heid (Germany), Pierre Corbin (France) and myself (U.K.), who rotate the executive editorship for one year at a time (the current calendar year being my own third turn). Although we knew that in terms of sales figures it would be an uphill struggle, we were keen from the beginning (a) to develop an international focus on dictionary research by encouraging a scholarly approach to outstanding issues, (b) to cultivate interdisciplinary contacts with many fields, from linguistics and cultural history to education and information technology, and - perhaps less successfully until very recently - (c) to promote interlingual topics such as pedagogical lexicography and translation.

All of this needed agreement among the editors and with the publisher on proper procedures for attracting, assessing, approving, producing and publicising the books we were to include in the series. From my files I see that by late 1983 we had worked out a contract and a set of guidelines for preparing copy, including the requirement of two positive editorial reports for accepting any manuscript for LexSM. Summaries in English (and sometimes French) are also asked for if the text is written in another language. Since then these rules have been elaborated, refined and partly computerised, and are made available to potential authors.

We have been concerned all along that publicity about LexSM should reach as wide a readership as possible, and the publisher has helped by producing a dedicated brochure (for volume numbers 1-87 in 1998), an annual catalogue as well as half-yearly leaflets, the latter usually with two to three LexSM items in each. Thus, the leaflet for I/2004 is advertising three volumes: Zita Hollós, on the topic of how to design a collocation-oriented German-Hungarian learner's dictionary, Jenny Thumb, on a think-aloud study of dictionary look-up strategies among Hong Kong learners of English, and the proceedings of a German conference on lexicography and its interdisciplinary contacts edited by Thomas Herbst et al. Copies of LexSM publications are regularly sent to periodicals for review and to book exhibitions at selected conferences. I myself have written reports on many of the volumes for the Annotated Biblio- 
graphy for English Studies ${ }^{2}$, and recently initiated an announcement about the series in relevant journals, newsletters and websites ${ }^{3}$.

Manuscripts have come from all over (including some from the editors themselves, e.g. Ladislav Zgusta's 1988 bibliography of metalexicography, Hans-Peder Kromann's jointly edited 1995 proceedings of a workshop on contrastive lexicology, Oskar Reichmann's co-authored 1995 book on hidden lexicographic information in Early New High German sources, and Ulrich Heid's 1997 study of how to structure monolingual and interlingual electronic dictionaries), but the European context has been predominant, "although no single profile has yet emerged of the typical country, the typical dictionary, and the typical lexicographer in Europe" (Hartmann 1993: 77). Links have always existed with both EURALEX (Volume 1 had presented the 55 papers of its first Congress, while the proceedings of subsequent congresses have been published by their respective host institutions) as well as the Dictionary Society of North America. But gradually, more and more countries outside Europe, and languages other than German and English, have come within our scope. The authors and editors of submitted manuscripts and published volumes have included both recognised authorities (like Herbert Ernst Wiegand, who had also been instrumental originally in getting both the book series and the yearbook series Lexicographica off the ground) and relative newcomers, e.g. authors of recent research dissertations, such as Ulrike Rothe's (2001) comparative study of the English and French 'dictionary scenes', and of the way(s) in which they may condition different lexicographic practices.

\section{Texts and topics}

LexSM volumes have exemplified several different text genres:

(a) Conference papers constitute a substantial proportion of published titles. At least 10 of these are devoted to the proceedings of the Symposium on Lexicography, a pioneering series of conferences held at Copenhagen every other year since 1982, which had helped to build bridges between theory and practice, Northern Europe and the rest of the world, and East and West (especially during the earlier phases when it offered an opportunity for scholars from both East and West Germany to meet). 11 symposia have been held so far, and the proceedings of all but the very first have been published in LexSM. Number VIII (1998) may be considered typical of this sub-series: edited by the founder, Arne Zettersten, and two of his colleagues, it consists of 22 papers by 24 authors typifying the 10 or so languages and countries that were represented at the 1996 Symposium, addressing such diverse issues as text compression, grammatical and semantic information, and translation equivalence. Of the many other conference proceedings published in LexSM, I will mention only two which are based on conferences held in 2002 and due to be 
issued later this year: one edited by CHAN Sin-Wei (Hong Kong) on the mutual relations between translation and bilingual lexicography, and the other edited by Julie Coleman (Leicester) and Anne McDermott (Birmingham) on the development of historical and period dictionaries.

(b) Anthologies and other collections bring together papers on related sets of topics by a single author (e.g. Herbert Ernst Wiegand's on semantics and lexicography, edited by Antje Immken and Werner Wolski 1999), by two authors (e.g. Jean-Claude Boulanger and Monique Cormier 2001 on personal names in French lexicography), or by a group of authors (e.g. Gerhard Augst et al. 1997 on German spelling dictionaries and Sue Atkins et al. 1998 on dictionary use), or papers delivered by a number of authors in one place over a period of time, e.g. (four) volumes of lectures from the Lexicography Colloquium at Heidelberg (Wiegand 2000).

(c) Bibliographies include Zgusta's (1988), but also a rather unique bibliography of dictionary bibliographies by Margaret Cop (1990), a bibliography of a total of 4863 monolingual and interlingual, general and specialised dictionaries of Dutch by Frans Claes and Peter Bakema (1995), and an annotated list of references on learners' dictionaries and the user perspective by Fredric Dolezal and Don McCreary (1999).

(d) Monographs comprise about half of the total LexSM list. They are typically based on specific research projects, some of which may be worth commenting on here.

Pedagogical lexicography is one subject which has grown in stature over the years, covering topics such as user surveys, from Turki Diab's (1990) report on dictionary use by Arab nursing staff to Ursula Wingate's (2002) observation of Chinese students of English and German, and learner-oriented dictionaries, from Humberto Hernández' (1989) analysis of Spanish school dictionaries via Ekkehard Zöfgen's (1994) discussion of French dictionaries for German learners to Martin Stark's (1999) study of the design features of the hybrid genre 'encyclopedic learner's dictionary' from the point of view of the user and Hilary Nesi's (2000) account of how foreign learners use and misuse EFL dictionaries.

Grammar in the dictionary is another recurring theme, which embraces such specialties as morphology and syntax (e.g. Edward McCorduck 1993), valency (e.g. Vilmos Ágel 1988), phraseology (e.g. Mi-Ae Cheon 1998) and collocations (e.g. Peter Howarth 1996).

Other information categories that have been treated in detail are pictorial illustrations (Werner Hupka 1989), usage labels (Michel Glatigny 1998), and translation equivalents (Gitte Baunebjerg Hansen 1990). 
Terminology, specialised dictionaries and languages for specific purposes have been examined, inter alia, from the point of medicine (strictly speaking a collection coordinated by Stephan Dressler and Burkhard Schaeder 1994) and accountancy (Franz Schneider 1998).

Computational lexicography is the term often used to refer to the evercloser relationship between lexicography and information technology, represented by the LexSM volumes by Matthias Kammerer (1995) on how to write dictionary entries on the computer screen, Thierry Fontenelle (1997) on how to extract semantic information from machine-readable dictionaries, and papers in the collection edited by Ingrid Lemberg et al. (2001) on how to support lexicography by electronic means.

Various lexicographic traditions have been investigated in detail, e.g. for English (Gabriele Stein 1985), for French (Margarete Lindemann 1994) and several other languages (and language pairs), including Greek (Evthymios Papachristos 1990), Tamil (Gregory James 1991), Hungarian (Rita Fejér 1995), Turkish (Hadi Yüksekkaya 1998), Polish (Agnieszka Frączek 1999), and Latvian (Ineta Balode 2002).

Some famous (and not so famous) lexicographers have received the attention of LexSM authors, e.g. John Wilkins and William Lloyd (Fredric Dolezal 1985), Matthias Kramer (Laurent Bray 2000), Antoine Furetière (Dorothea Behnke 1996), and Jacob and Wilhelm Grimm (two volumes prepared by a collective led by Alan Kirkness et al. 1991).

(e) Textbooks include Burkhard Schaeder's (1987) introduction to lexicography within the confines of German studies.

(f) Dictionaries themselves have not been neglected, and include both entirely new ones and reprints of classics, e.g. the Chinese-English dictionary of idioms and proverbs by HENG Xiao-Jun and ZHANG Xue-Zhi (1988), the dictionary of Yiddish loan-words in German dialects by Heidi Stern (2000), and new editions of Daniel Sanders' German thesaurus (Peter Kühn 1985) and of Jean-François Féraud's Dictionaire Critique (Philippe Caron and Terence Wooldridge 1994).

\section{Strains and satisfactions}

59 LexSM titles have been cited in this article, an arbitrarily chosen cross-section of $50 \%$ of those published so far, including two that are forthcoming later in 2004. But progress has not always been even, and relations between our respective offices and the outside world have not always been straightforward. For a start, the editors can bring their attention only to what they are offered, 
and they very rarely get the chance of initiating a publication unless they take it on themselves (see Section 2 above) or encourage others, such as colleagues, visiting fellows or doctoral students they have supervised or examined to write up their research (I am proud that more than 10\% of the cited titles are the result of my own intervention through such channels). It may well be the case that we have not (yet) dealt with certain topics that may be of particular interest to individual editors. And if a manuscript on such a subject finally emerges, it sometimes has to be turned down because of formal deficiencies. It even happens that an author or editor of a manuscript accepted for LexSM decides to take it to a different publisher. Thus I was personally very disappointed when we lost a volume on the lexicography of American Indian languages (edited by William Frawley et al. 2002).

There have been other losses, too, for instance when one of the editors, Hans-Peder Kromann, died prematurely and after completing only one round of executive editorship. And there are issues that have never been fully resolved, for example, how the loose links we have enjoyed with EURALEX and DSNA from the start should have been formalised, and whether similar links should be established with other continental, regional or subject societies.

Among the positive highlights has been the feeling that we can observe, sometimes even promote, progress in relatively neglected areas. One of these has been dictionary criticism, where we have definitely noticed considerable advances over the years, not least by the contributions of the periodical Lexicon published by the Iwasaki Linguistic Circle in Tokyo. Within LexSM, Martha Ripfel (1989) analysed the texts of 736 reviews of five dictionaries, and Herbert Ernst Wiegand commissioned teams of experts to evaluate and assess prototypical dictionaries. Based on the earlier 'grilling' of two German dictionaries for foreign learners (Langenscheidt and De Gruyter), Wiegand's (2003) meticulous examination, in the first of two volumes dedicated to the Duden. Das große Wörterbuch der deutschen Sprache in zehn Bänden, consisted of 29 contributions by 31 authors arranged in six chapters, ranging from comparisons with other 'national' dictionaries and other Duden dictionaries to this dictionary's treatment of semantics, grammar and regional vocabulary. Seven more chapters on multifarious structures and information categories in both the print and electronic versions of the well-known 10-volume general-purpose dictionary are planned for the second volume, which is in preparation.

Sometimes a book takes a long time to materialise, and there is then great personal satisfaction when something that you had almost given up hope for sees the light of day. One example was the long gestation of the book on the methodology of user studies by Yukio Tono (2001), which I had encouraged ever since we had made contact many years ago, but which when it finally appeared set new standards.

Lastly, an illustration of both high and low points. Ladislav Zgusta has been well represented in LexSM (and I have publicly acknowledged my indebtedness to him by reprinting part of his (1971) Manual of Lexicography in my 
3-volume reader Lexicography: Critical Concepts, Hartmann 2003). Some years ago, when I heard that a festschrift was planned to honor this all-time 'great', I was ready to offer my own contribution to the two editors (Braj Kachru and Henry Kahane 1995). However, as this was couched in terms of a transcontinental trialogue (between 'Lex', 'Dox' and 'Fax') rather than presented in the form of a conventional paper, it was turned down [and eventually published elsewhere: Hartmann (1994)].

\section{Some final thoughts}

So what has been accomplished? Has LexSM made an impact? Has the series increased general awareness about lexicography and its problems and pleasures? Based on the evidence of impressive sales achieved (6 of the first 20 volumes now out of print) and positive reviews received, I certainly think so. One of the things I have enjoyed most is the privilege of judging some of the best contributions to lexicography and thus supporting its maturation into a scholarly discipline, although it is still considered an inferior minority subject in academic circles, and contacts between LexSM editors and authors are therefore often by word of mouth. What I am most happy about, though, is the fact that the series has become the only truly representative organ for all aspects of our specialism world-wide.

\section{Notes}

1. I am grateful to the editor of Lexikos, J.C.M.D. du Plessis, for encouraging me to report on my experiences as one of the editors of LexSM. Although I have shown a draft to my fellow editors for comment, I alone remain responsible for its contents.

2. Between 1994 and 2004, I compiled more than 20 entries on LexSM titles for this on-line service. Website: <http://abes.swets.nl/abes/>.

3. Contact details: For more information on titles issued since Volume 95, consult the website of our publisher, Max Niemeyer (Tübingen): <www.niemeyer.de $>$. As one of the seven editors of the series (executive for the current calendar year 2004), I would be keen to hear from you if you have a manuscript to submit or know of a proposal for one. Please write to Reinhard Hartmann by email (above) or: 40 Velwell Road, Exeter, Devon EX4 4LD, U.K.

\section{References}

Ágel, V. 1988. Überlegungen zur Theorie und Methode der historisch-synchronen Valenzsyntax und Valenzlexikographie. LexSM 25. Tübingen: M. Niemeyer.

Atkins, B.T.S. (Ed.). 1998. Using Dictionaries. Studies of Dictionary Use by Language Learners and Translators. LexSM 88. Tübingen: M. Niemeyer.

Augst, G. et al. 1997. Rechtschreibwörterbücher im Test. LexSM 78. Tübingen: M. Niemeyer. 
Balode, I. 2002. Deutsch-lettische Lexikographie. Eine Untersuchung zu ihrer Tradition und Regionalität im 18. Jahrhundert. LexSM 111. Tübingen: M. Niemeyer.

Baunebjerg Hansen, G. 1990. Artikelstruktur im zweisprachigen Wörterbuch. LexSM 35. Tübingen: M. Niemeyer.

Behnke, D. 1996. Furetière und Trévoux. Eine Untersuchung zum Verhältnis der beiden Wörterbuchserien. LexSM 72. Tübingen: M. Niemeyer.

Boulanger, J.-C. and M.C. Cormier. 2001. Le nom propre dans l'espace dictionnairique général. LexSM 105. Tübingen: M. Niemeyer.

Bray, L. 2000. Matthias Kramer et la lexicographie du français en Allemagne au XVIIIe siècle. LexSM 99. Tübingen: M. Niemeyer.

Caron, P. and T.R. Wooldridge (Eds.). 1994. Jean-François Féraud: Dictionaire Critique de la Langue Française (1787). LexSM 51-53. Tübingen: M. Niemeyer.

Chan, S.-W. (Ed.). 2004. Translation and Bilingual Dictionaries. LexSM 119. Tübingen: M. Niemeyer.

Cheon, M.-A. 1998. Zur Konzeption eines phraseologischen Wörterbuchs für den Fremdsprachler. Am Beispiel Deutsch-Koreanisch. LexSM 89. Tübingen: M. Niemeyer.

Claes, F. and P. Bakema. 1995. A Bibliography of Dutch Dictionaries. LexSM 67. Tübingen: M. Niemeyer.

Coleman, J. and A. McDermott (Eds.). 2004. Dictionary History and Historical Lexicography. LexSM 123. Tübingen: M. Niemeyer.

Cop, M. 1990. Babel Unravelled. An Annotated World Bibliography of Dictionary Bibliographies, 16581988. LexSM 36. Tübingen: M. Niemeyer.

Diab, T. 1990. Pedagogical Lexicography. A Case Study of Arab Nurses as Dictionary Users. LexSM 31. Tübingen: M. Niemeyer.

Dolezal, F.T. 1985. Forgotten but Important Lexicographers: John Wilkins and William Lloyd. LexSM 4. Tübingen: M. Niemeyer.

Dolezal, F.T. and D.R. McCreary. 1999. Pedagogical Lexicography Today. A Critical Bibliography on Learners' Dictionaries with Special Emphasis on Language Learners and Dictionary Users. LexSM 96. Tübingen: M. Niemeyer.

Dressler, S. and B. Schaeder (Eds.). 1994. Wörterbücher der Medizin. Beiträge zur Fachlexikographie. LexSM 55. Tübingen: M. Niemeyer.

Fejér, R. 1995. Zur Geschichte der deutsch-ungarischen und ungarisch-deutschen Lexikographie. LexSM 60. Tübingen: M. Niemeyer.

Fontenelle, T. 1997. Turning a Bilingual Dictionary into a Lexical-Semantic Database. LexSM 79. Tübingen: M. Niemeyer.

Frączek, A. 1999. Zur Geschichte der deutsch-polnischen und polnisch-deutschen Lexikographie (17721868). LexSM 93. Tübingen: M. Niemeyer.

Frawley, W. et al. (Eds.). 2002. Making Dictionaries. Preserving Indigenous Languages of America. Berkeley: University of California Press.

Glatigny, M. 1998. Les marques d'usage dans les dictionnaires français monolingues du XIXe siècle. LexSM 91. Tübingen: M. Niemeyer.

Goebel, U. et al. 1995. Versteckte lexikographische Information. LexSM 65. Tübingen: M. Niemeyer.

Hartmann, R.R.K. 1988. IJL salutes Lexicographica. Lexicographica Series Maior - The first 20 volumes. International Journal of Lexicography 1(2): 151-152.

Hartmann, R.R.K. 1993. General Lexicography in Europe. Lexikos 3: 67-82. 
Hartmann, R.R.K. 1994. The bilingualised learner's dictionary (A transcontinental trialogue on a relatively new genre). James, G. (Ed.). 1994. Meeting Points in Language Studies: 171-183. Hong Kong: The Hong Kong University of Science and Technology Language Centre.

Hartmann, R.R.K. 2000. European lexicography. Dictionaries. Journal of the Dictionary Society of North America 21: 1-21.

Hartmann, R.R.K. (Ed.). 1984. LEXeter '83 Proceedings. Papers from the International Conference on Lexicography at Exeter, 9-12 September 1983. LexSM 1. Tübingen: M. Niemeyer.

Hartmann, R.R.K. (Ed.). 2003. Lexicography: Critical Concepts [3 volumes]. London: Routledge.

Hausmann, F.J. et al. (Eds.). 1989-1991. Wörterbücher. Ein internationales Handbuch zur Lexikographie/Dictionaries. An International Encyclopedia of Lexicography/Dictionnaires. Encyclopédie internationale de lexicographie. Handbücher zur Sprach- und Kommunikationswissenschaft Volumes 5.1-5.3. Berlin: W. de Gruyter.

Heid, U. 1997. Zur Strukturierung von einsprachigen und kontrastiven elektronischen Wörterbüchern. LexSM 77. Tübingen: M. Niemeyer.

Heng, X.-J. and X.-Z. Zhang. 1988. A Chinese-English Dictionary of Idioms and Proverbs. LexSM 24. Tübingen: M. Niemeyer.

Herbst, T. et al. (Eds.). 2004. Lexikografie, ihre Basis- und Nachbarwissenschaften. LexSM 118. Tübingen: M. Niemeyer.

Hernández, H. 1989. Los diccionarios de orientación escolar. LexSM 28. Tübingen: M. Niemeyer.

Hollós, Z. 2004. Lernerlexikographie: syntagmatisch. LexSM 116. Tübingen: M. Niemeyer.

Howarth, P.A. 1996. Phraseology in English Academic Writing. LexSM 75. Tübingen: M. Niemeyer.

Hupka, W. 1989. Wort und Bild. Die Illustrationen in Wörterbüchern und Enzyklopädien. LexSM 22. Tübingen: M. Niemeyer. [Section 8.7 'Fallstudie/Case Study' updated, translated and reprinted in Hartmann 2003, Vol. III: 363-390.]

Immken, A. and W. Wolski. (Eds.). 1999. Herbert Ernst Wiegand: Semantics and Lexicography. Selected Studies (1976-1996). LexSM 97. Tübingen: M. Niemeyer.

James, G. 1991. Tamil Lexicography. LexSM 40. Tübingen: M. Niemeyer.

Kachru, B.B. and H. Kahane (Eds.). 1995. Cultures, Ideologies, and the Dictionary. Studies in Honor of Ladislav Zgusta. LexSM 64. Tübingen: M. Niemeyer.

Kammerer, M. 1995. Bildschirmorientiertes Abfassen von Wörterbuchartikeln. LexSM 68. Tübingen: M. Niemeyer.

Kirkness, A. et al. (Eds.). 1991. Studien zum Deutschen Wörterbuch von Jacob Grimm und Wilhelm Grimm. LexSM 33/34. Tübingen: M. Niemeyer.

Kromann, H.-P. and A.L. Kjær (Eds.). 1995. Von der Allgegenwart der Lexikologie. LexSM 66. Tübingen: M. Niemeyer.

Kühn, P. (Ed.). 1985. Daniel Sanders: Deutscher Sprachschatz [Nachdruck der Ausgabe Hamburg 1873-1877]. LexSM 6/7. Tübingen: M. Niemeyer.

Lemberg, I. et al. (Eds.). 2001. Chancen und Perspektiven computergestützter Lexikographie. LexSM 107. Tübingen: M. Niemeyer.

Lindemann, M. 1994. Die französischen Wörterbücher von den Anfängen bis 1600. LexSM 54. Tübingen: M. Niemeyer.

McCorduck, E.S. 1993. Grammatical Information in ESL Dictionaries. LexSM 48. Tübingen: M. Niemeyer.

Nesi, H. 2000. The Use and Abuse of EFL Dictionaries. LexSM 98. Tübingen: M. Niemeyer. 
Papachristos, E.C. 1990. Die deutsch-neugriechische Lexikographie von 1796-1909. LexSM 32. Tübingen: M. Niemeyer.

Reichmann, O. [see Goebel et al.]

Ripfel, M. 1989. Wörterbuchkritik. Eine empirische Analyse von Wörterbuchrezensionen. LexSM 29. Tübingen: M. Niemeyer.

Rothe, U. 2001. Das einsprachige Wörterbuch in seinem soziokulturellen Kontext. LexSM 108. Tübingen: M. Niemeyer.

Schaeder, B. 1987. Germanistische Lexikographie. LexSM 21. Tübingen: M. Niemeyer.

Schneider, F. 1998. Studien zur kontextuellen Fachlexikographie. Das deutsch-französische Wörterbuch der Rechnungslegung. LexSM 83. Tübingen: M. Niemeyer.

Stark, M.P. 1999. Encyclopedic Learners' Dictionaries. LexSM 92. Tübingen: M. Niemeyer.

Stein, G. 1985. The English Dictionary before Cawdrey. LexSM 9. Tübingen: M. Niemeyer.

Stern, H. 2000. Wörterbuch zum jiddischen Lehnwortschatz in den deutschen Dialekten. LexSM 102. Tübingen: M. Niemeyer.

Thumb, J. 2004. Dictionary Look-up Strategies and the Bilingualised Learner's Dictionary. LexSM 117. Tübingen: M. Niemeyer.

Tono, Y. 2001. Research on Dictionary Use in the Context of Foreign Language Learning. LexSM 106. Tübingen: M. Niemeyer.

Wiegand, H.E. 2003. Untersuchungen zur kommerziellen Lexikographie der deutschen Gegenwartssprache I (Duden). LexSM 113. Tübingen: M. Niemeyer.

Wiegand, H.E. (Ed.). 2000. Wörterbücher in der Diskussion IV. Vorträge aus dem Heidelberger Lexikographischen Kolloquium. LexSM 100. Tübingen: M. Niemeyer.

Wingate, U. 2002. The Effectiveness of Different Learner Dictionaries. LexSM 112. Tübingen: M. Niemeyer.

Yüksekkaya, H.Y. 1998. Die deutsch-türkische Lexikographie. LexSM 85. Tübingen: M. Niemeyer.

Zettersten, A. et al. (Eds.). 1998. Symposium on Lexicography VIII. Proceedings of the Eighth International Symposium on Lexicography May 2-4, 1996, at the University of Copenhagen. LexSM 90. Tübingen: M. Niemeyer.

Zgusta, L. 1971. Manual of Lexicography. Janua Linguarum. Series Maior 39. Prague: Academia/The Hague: Mouton. [pp. 345-357 updated and reprinted in Hartmann 2003, Vol. I: 70-82.]

Zgusta, L. [with the assistance of D.M.T.Cr. Farina]. 1988. Lexicography Today. An Annotated Bibliography of the Theory of Lexicography. LexSM 18. Tübingen: M. Niemeyer.

Zgusta, L. 1991. Probable Future Developments in Lexicography. Hausmann, F.J. et al. (Eds.). 19891991, Vol. III: 3158-3168.

Zöfgen, E. 1994. Lernerwörterbücher in Theorie und Praxis. LexSM 59. Tübingen: M. Niemeyer. 